\title{
LANGUAGE
}

@

\author{
Justyna Mandziuk \\ Maria Curie-SkŁodowska University (UMCS) in Lublin \\ MANDZIUK.JUSTYNA@GMAIL.COM
}

\section{Why Money Cannot Buy Happiness. The Painful Truth about Traditional Proverbs and Their Modifications}

\begin{abstract}
Can one imagine language without proverbs? Do we really need these somewhat clichéd adages like An apple a day keeps a doctor away, Once bitten, twice shy, or Crime doesn't pay? Are they still influential, or perhaps modern society should give them a new lease of life?

This paper aims to reveal the "painful truth" behind traditional proverbs and especially their modified versions. Leading paremiologists (Wolfgang Mieder, Nihada Delibegović Džanic, Anna Litovkina) introduce a number of terms in reference to the latter, and so this study discusses the etymology and the semantic import of such labels as anti-proverbs, twisted proverbs, quasi-proverbs, and pseudo-proverbs. However, its basic aim is to propose a classification of modified proverbs based on a number of examples, such as Man proposes, mother-in-law opposes; A good beginning is half the bottle; Crime pays - be a lawyer; A new broom sweeps clean, but the old one knows the corners, and many others. Finally, based on Ronald Langacker's conception of the profile-base distinction, deriving from the figure-ground alignment, this paper makes an attempt to prove the necessary link between traditional proverbs and their innovative modifications.
\end{abstract}

Key words: paremiology, modified proverbs, perverbs, anti-proverbs, quasi-proverbs, pseudo-proverbs, twisted proverbs

\section{Introduction}

Traditional proverbs are frequently perceived as words of great wisdom and morals of a given culture that are passed on from one generation to another. They encapsulate enchanting viewpoints and perceptions of various linguistic communities, captured 
in concise forms, yet not necessarily with obvious meanings. Following the authors who discuss proverbs and their modifications (e.g. Taylor 1931, Norrick 1985, Valdaeva 2003, Mieder 2004, Mierzwińska-Hajnos 2013), ${ }^{1}$ this paper offers an insight into traditional proverbs, but with a special focus on their innovative modifications. Their seemingly unlimited linguistic variations result in ingenious expressions which may be called perverbs, modified proverbs, twisted proverbs, anti-proverbs, pseudo- or quasi-proverbs.

The aim of this paper is thus threefold: (1) to define what we can call traditional proverbs and identify their elementary features; (2) to bring order to the inconsistent and sometimes chaotic terminology used in modern paremiology (cf. Mandziuk 2016); and finally (3) to consider whether modifications to proverbs are somehow limited and what rules, if any, new proverbs should follow in order to be still included in the category traditional proverbs. Finally, we ask whether traditional proverbs powerful enough to stand the test of time.

\section{Traditional proverbs and their peculiarities}

In this section, an attempt is made to define traditional proverbs and to propose a list of their crucial features. This issue is signalled in Mandziuk (2016) and now I wish to discuss it in more details. Looking at such traditional, well-entrenched proverbs as Once bitten, twice shy, When there is a will there is a way, or An apple a day keeps a doctor away in isolation, one may come to the conclusion that the majority of traditional sayings follow similar patterns, thanks to which they acquire true paremiological status. In order to successfully identify the inherent traits of long-established proverbs, let us invoke Wolfgang Mieder's definition of a proverb as "a short, generally known sentence of the folk which contains wisdom, truth, morals and traditional views in a metaphorical, fixed and memorisable form and which is handed down from generation to generation" (Mieder 1993: 5). This approach may be calibrated with the concept of proverbs proposed by Neal Norrick, who claims that "the proverb is a traditional, conventional, didactic genre with general meaning, a potential free conventional turn, preferably with figurative meaning" (Norrick 1984: 78). Besides, Lord John Russell points out that “a proverb is one man's wit and all men's wisdom”. A peculiar approach to proverbs is that of Bartlett-Jere Whiting, who in a jocular fashion says that a proverb "is usually short, but need not be; it is usually true, but need not be..." (Whiting 1994: 80). It appears from these quotations that one uncontroversial and universally applicable definition of a proverb is perhaps impossible to construct. However, it should be possible to list the general features identifiable in most prover-

For more background on proverbs, cf. Honeck (1997), Kuźniak (2005), Winick (2013), or Hrisztova-Gotthardt and Varga (2015). 
bial expressions. An attempt to formulate such a list, based on the above presented definitions and my own observations, is the following:

1. Proverbs are concise in form, with a relatively schematic, patterned structure.

2. They contain a didactic kernel of truth.

3. They convey advice.

4. They encapsulate general wisdom in a figurative manner.

5. They are timeless in the sense of pertaining to human nature in general, rather than to specific, "local" situations.

6. They are memorable and melodious thanks to such stylistic devices as rhyme, rhythm, alliteration, repetition of lexical content or structure, etc.

7. They are shared by a community of speakers.

8 . They are not identified with any specific author.

9. Ideally they are inherited from former generations of speakers.

10. They are deeply-entrenched in and popular with a given community of speakers.

Not all of these principles can be applied to every proverb: the first two points seem to be essential, the remaining eight may or may not be present. One may hypothesise that it is enough for a proverb to exhibit most of these ten properties in order to be labelled a legitimate member of the proverbial family. As is the case with other linguistic categories, proverbs cannot be classified in a binary fashion. In other words, analysing expressions as either proverbial or non-proverbial, without any residue or middle ground, may appear questionable. Although language does not follow binary logic, some guiding principles are certainly helpful while classifying proverbs. Besides, the above enumerated features do not constitute a fixed and stable set and do leave room for individual interpretation. Other important factors include a speaker's subjective response to specific proverbs: after all, one man's meat is another man's poison.

We are slowly touching upon the problem of the original and the modified proverbs. Other variations of the "meat-poison" proverb include: One man's garbage is another man's art; One man's pleasure is another man's pain; One man's loss is another man's gain/profit; One man's junk/trash/rubbish is another man's treasure. Which of these is the original proverb and which ones are its modifications? It appears that the root proverb from which all others have been derived is One man's meat is another man's poison: it's first appearance in print dates back to the $1^{\text {st }}$ century B.C., when it was first used by the Latin writer Lucretius. ${ }^{2}$ In England this proverb was popularised by the playwright Thomas Middleton, with all the other extensions being later coined on the basis of the original form.

It is possible to classify proverbs according to the prototype model of categorisation. The proverbs that meet all the criteria listed above may be called prototypical proverbs. One of them, in my opinion, is the deeply-entrenched An apple a day keeps

2 Cf.http://www.bloomsbury-international.com/en/student-ezone/idiom-of-the-week/list-of-itioms/1358-one-mans-meat-is-another-mans-poison.html, retrieved 20 February 2016. 
a doctor away. First, it is brief (and, to paraphrase a known adage, brevity is the soul of a proverb); besides, its component parts cannot be replaced with any other linguistic items (note that this criterion is restricted to "core" or traditional proverbs only). Second, it has a didactic aspect with a great dose of medical truth: it has been proved that apples are a good source of vitamins, anti-oxidants and fiber; eaten regularly, they may protect a person from heart diseases, strokes or cancers. Apart from that, apples serve as marvelous toothbrushes, which effectively sweep away bacteria and, thus, lower the risk of tooth decay. Third, the advice offered in this proverb may be the following: "eat apples as they are good for your health". Four, the proverb has a figurative meaning thanks to its metaphorical nature. ${ }^{3}$ Fiveh, the adage is timeless: note that one of its first, recorded appearances came over two centuries ago, in the February 1866 issue of Notes and Queries magazine. Over time, it has only transformed from somewhat longish form, Eat an apple on going to bed, and you'll keep the doctor from earning his bread, into the much-cited phrase. Six, this proverb is memorable and catchy thanks to its rhyme and rhythm. The accumulation of $a$ 's in word-initial positions (alliteration) also plays a mnemonic role. Seven, this proverb appears to be very popular and thus well-known. Eight, its origin cannot be attributed to an author known by name. Nine, it has been inherited from previous generations (cf. also point five above). Ten, An apple a day... is commonplace. It is well-entrenched and serves as the title for numerous articles and books, for example the one that served as my inspiration for writing this paper, namely An Apple A Day: Old-Fashioned Proverbs and Why They Still Work by Caroline Taggart (2009). It is frequently alluded to in numerous lyrics ${ }^{4}$ and nursery rhymes, e.g.

An apple a day keeps the doctor away.

Apple in the morning, doctor's warning.

Roast apple at night, starves the doctor outright.

Eat an apple going to bed, knock the doctor on the head.

Three each day, seven days a week, ruddy apple, ruddy cheek.

3 In the sense of conceptual metaphor, as proposed by Lakoff and Johnson: "metaphor is pervasive in everyday life, not just in language but in thought and action. Our ordinary conceptual system, in terms of which we think and act, is fundamentally metaphorical in nature" (Lakoff and Johnson 2003 [1980]: 4). Originally, the Latin word metaphora meant 'carrying over', from Greek metaphora 'transfer'. Conceptual metaphor is a transfer of meaning from one (source) domain to another (target) domain. Thus, in conceptual metaphor one domain of experience is understood with reference to another domain of experience.

In the proverb An apple a day keeps a doctor away the key to unlock this conceptualisation lies in the word apple, which stands for fruit generally. The names of specific fruits are of secondary importance, since all fruit consumed in appropriate amounts is generally healthy and nutritious.

4 A lyric entitled "An Apple A Day" is available on http://www.azlyrics.com/lyrics/aqua/anappleaday.html retrieved in February 2016. Note, that this example contains an anti-proverb: An apple a day won't keep a doctor away. 
Moreover, modern advertising business relies heavily on the persuasive power of proverbs, frequently building its eye-catching slogans upon their structure. As an illustration, consider the advertisement by the Lambton Shopping Mall (Figure 1a).

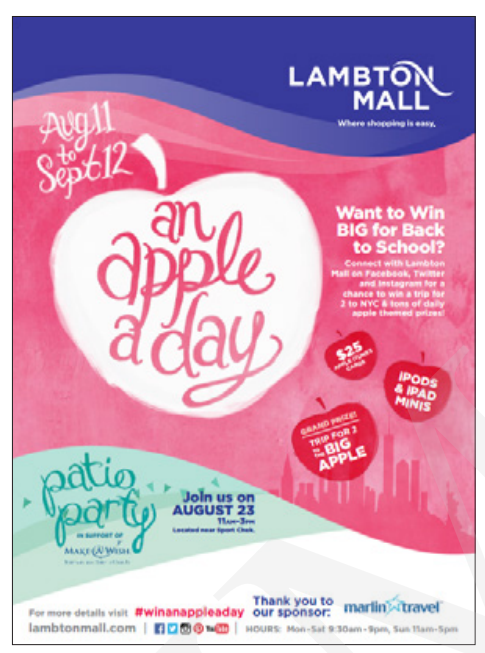

Figure 1a. Advertisement of the Lambton Mall (http://click-sarnia.com/apple-day-lambton-mall-contest/, retrieved 20 February 2016)

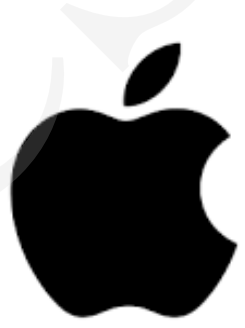

Figure 1b. Apple Inc. logo

(C) Apple Inc.)

It is clear that this piece of promotional material is formed upon the popular proverb An apple a day keeps a doctor away. Crucially, the key word apple has a double meaning. It obviously alludes to the proverb, while on the second look one may uncover the hidden, intended meaning, namely a reference to Apple Inc. multinational technology company which specialises in iPhones, iPads and other electronic devices (cf. its logo in Figure 1b). Lambton Mall tries to encourage prospective buyers to come and do their shopping in its centre because every customer has a chance to win one of many Apple themed accessories. Through this ingenious marketing trick, copywriters strengthen the advertisement's potential. Besides, allusions to tradition and heritage from former generations augments the trust in the company's potential customers, which in turn encourages them to do the shopping.

\section{Classification of modified proverbs}

The preceding section presents traditional proverbs, specifically with a view to their elementary proverbial features. With the example of An apple a day keeps a doctor away I have tried to show that traditional proverbs are characterised by all ten properties identified as essential categorial features. But do new proverbs follow the same principles or should they be treated as belonging to different categories? 
Why Money Cannot Buy Happiness. The Painful Truth about Traditional Proverbs... 9

According to Wolfgang Mieder, modified proverbs involve "a fascinating interplay of tradition and innovation" (Mieder 1993: 10); they are "old wisdom in new clothing" Equipped with the general outlook on both traditional and new proverbs, we are now ready to systematise the terminology (cf. Mandziuk 2016), often rather chaotic, used in the paremiological literature: modified proverbs, perverbs, twisted, anti-, pseudo- and quasi-proverbs. Although Mieder (2004: 28) and Nihada Delibegović Džanić (2007) treat these terms as synonymous, it is doubtful that they can be so treated. I would like to delve into a possible classification of these terms (signalled in Mandziuk 2016), diagrammed in Figure 2.

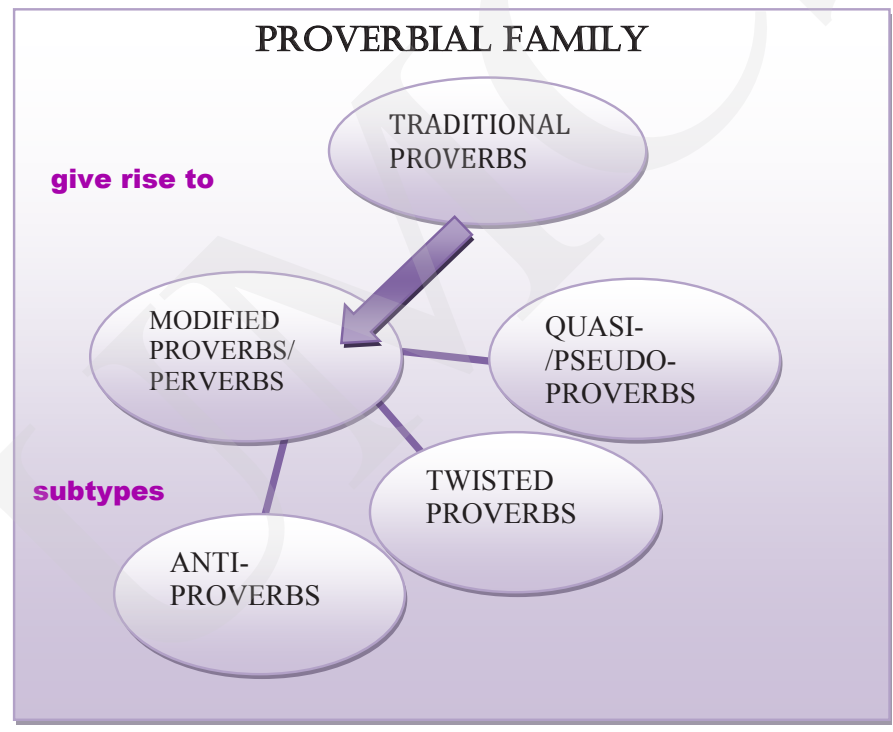

Figure 2. The "proverbial tree". Traditional proverbs and subcategories of their modifications

The hierarchical structure of Figure 2 shows the terms perverbs or modified proverbs as clearly foregrounded. In my opinion, they encapsulate all the other subcategories (i.e. twisted, anti- and quasi-proverbs) and thus may serve as an umbrella category. Etymologically, the term perverb can be analysed as a result of blending or a portmanteau word creation. In the process, usually the initial morpheme of one word is combined with the final morpheme of the other. According to Online Etymology Dictionary, the word proverb derives from the Latin proverbium 'a common saying, old adage, maxim', which in turn may be further broken into two separate meaningful units: pro- 'forth' + verbum 'word' + the Latin suffix -ium. Accordingly, the word perverted 'turned from the right way' may be divided into the morphemes per- 'away' + vertere 'to turn'. Then the words perverted and proverb are blended into perverb. The process is summarised in diagrammatic form in Figure 3. 


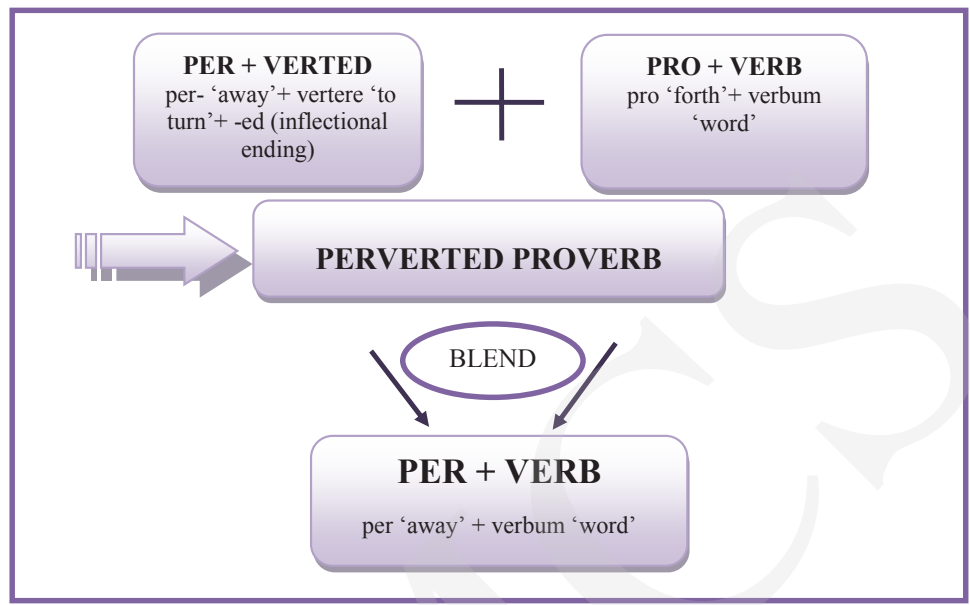

Figure 3. Etymology of perverb

The term modified proverb, in turn, shares semantically with the verb to pervert the notion of change. Therefore, both labels, perverb and modified proverb, are very broad and general and for our purposes may be treated as synonyms.

Mieder (2004) provides a general definition of the concept of anti-proverb, claiming that it is "an intentionally changed (twisted, parodied) proverb with a new meaning” (Mieder 2004: 281). This definition seems only partlly adequate. While it true to say that anti-proverbs introduce a new semantic content (it happens so by means of the process called relexicalisation, which introduces new meanings through lexical and stylistic changes), the etymology of the prefix anti- suggests something 'opposing, against', 5 rather than parodied or twisted. Accordingly, anti-proverbs produce meanings that stand in contrast to the original ones. Moreover, they might add utterly new dimensions to the bon a fide proverbs in such a way that the traditional meanings are seriously altered. As an illustration consider Money may not buy happiness, but most of us are willing to make an experiment, or Never do today what you can put off for tomorrow. While the former instance introduces a new perspective into the original proverb by means of the conjunction but, the latter anti-proverb contradicts the original version (i.e. Never put off for tomorrow what you can do today) through a syntactic shift. In fact, there are at least four possible patterns thanks to which original proverbs can be converted into their anti-versions, i.e.:

i. reversal of word order, e.g. Leap before you look vs. the original proverb Look before you leap;

ii. asking questions, e.g. If practice makes perfect and nobody is perfect then why practice?

5 http://www.etymonline.com/index.php?allowed_in_frame=0\&search=anti and http://www.collinsdictionary.com/dictionary/english/anti?showCookiePolicy=true, retrieved 15 March 2016. 
Why Money Cannot Buy Happiness. The Painful Truth about Traditional Proverbs... 11

iii. turning positive statements into negative ones and vice versa e.g. Beggars can be choosers;

iv. addition of a dubious tag by means of conjunctions such as but, if, yet, however, (al)though etc., e.g. Love is blind, but neighbours aren't.

An inherent property of anti-proverbs is the fact that they contradict or negate the original ones. However, some pairs of bona fide proverbs also express conflicting pieces of wisdom. Let us consider such pairs as of traditional proverbs as:

- Look before you leap vs. He who hesitates is lost;

- Too many cooks spoil the broth vs. Many hands make light work;

- Haste makes waste vs. Time waits for no man;

- It's better to be safe than sorry vs. Nothing ventured, nothing gained.

All these instances show that traditional proverbs may be as confusing as anti-proverbs. However, there is one substantial difference between traditional and anti-proverbs. While a traditional proverb may contradict another traditional proverb (thus the conflicting pair is made up of two separate bona fide proverbs), anti-proverbs juxtapose an original proverb with a new, anti-version of it to effect a contradictory pair.

The next term, quasi-proverb, seems to have negative connotations. For the purpose of this study, we can assume that it can be used interchangeably with its sister-term pseudo-proverb, since both denote sayings which are false, merely pretending to be true or genuine. In other words, they seem to be unsuccessful modifications that do not fulfil elementary proverbial requirements. That is why, with the terms quasiand pseudo-proverb used somewhat pejoratively, the modified variants may be seen as not only unsuccessful modifications but also ones that express false truth and pseudo-wisdom. However, quasi-proverbs are based on proverbial grounds and as long as they are easily identified with the traditional proverb they should not be excluded from the "proverbial family". While it is true to say that quasi-proverbs are not prototypical modified adages, they do belong to this category as its marginal members. For example, the quasi-proverb Early to bed and early to rise and it probably means your TV set is being repaired (Mieder 1991: 90) contains a kernel of truth in that modern society lives in the world of TV and PC screens - but in fact this pseudo-proverb is neither concise (on the contrary, it is rather lengthy), nor memorable, since there are no stylistic devices that would render it smooth and melodious in tone. Another example is Early to bed and early to rise and your friend will wonder why you can't get a job with better hours (ibid.). This one is an exemplary quasi-proverb, which fails to be characterised by any of the 10 proverbial features.

Finally, there are twisted proverbs (Mieder and Litovkina 1999), which may be regarded as the most fruitful and productive subgroup of modified proverbs. One characteristic feature that distinguishes them from quasi-proverbs is the fact that they undergo various lexical, conceptual and phonetic modifications. As an illustration consider He who laughs last, thinks slowest, which involves lexical substitution in the second part (cf. the original version He who laughs last, laughs best). Moreover, a slight phonetic play on sounds may be noticed in the twisted proverb Curiosity thrilled the cat. 
An almost unnoticeable change of a few letters, i.e. thrilled instead of the original killed, results in a witty and enchanting book title. ${ }^{6}$

Twisted proverbs are the most productive category and in fact they might often be encountered in various newspapers, cartoons, article headlines, advertising slogans, company logos etc. Table 1 lists all the subcategories of proverbs discussed above, providing their conspicuous characteristics and classic examples.

Table 1. Traditional proverbs and categories of their modified variants (perverbs)

\begin{tabular}{|c|c|c|c|c|}
\hline & \multirow{2}{*}{ PROVERBS } & \multicolumn{3}{|c|}{ MODIFIED PROVERBS / PERVERBS } \\
\hline & & ANTI-PROVERBS & $\begin{array}{c}\text { TWISTED } \\
\text { PROVERBS }\end{array}$ & QUASI-PROVERBS \\
\hline 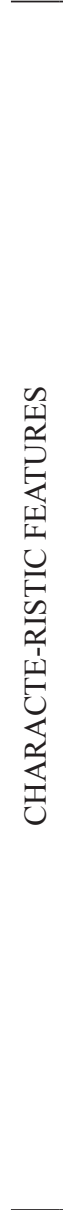 & $\begin{array}{l}\text { - concise and pat- } \\
\text { terned with schemat- } \\
\text { ic structure } \\
\text { - contain a didactic } \\
\text { kernel of truth } \\
\text { - covey advice } \\
\text { - encapsulate general } \\
\text { wisdom in a figura- } \\
\text { tive manner } \\
\text { - timeless in the } \\
\text { sense of pertaining } \\
\text { to human nature in } \\
\text { general, rather than } \\
\text { to specific, "local" } \\
\text { situations } \\
\text { - memorable and } \\
\text { melodious thanks } \\
\text { to such stylistic } \\
\text { devices as rhyme, } \\
\text { alliteration etc. } \\
\text { - shared by a commu- } \\
\text { nity of speakers } \\
\text { - anonymous } \\
\text { - inherited from previ- } \\
\text { ous generations } \\
\text { - deeply-entrenched } \\
\text { in and popular with } \\
\text { that community of } \\
\text { speakers }\end{array}$ & $\begin{array}{l}\text { - anti means 'oppos- } \\
\text { ing', 'against', 'in } \\
\text { front of' } \\
\text { - introduce new } \\
\text { meaning or oppose } \\
\text { the one expressed in } \\
\text { original proverbs } \\
\text { - doubt, contradict, } \\
\text { reverse or seriously } \\
\text { undermine messages } \\
\text { of original proverbs } \\
\text { - frequently dou- } \\
\text { ble-barreled units, } \\
\text { where the first half } \\
\text { comes directly } \\
\text { from a traditional } \\
\text { proverb, while the } \\
\text { second half intro- } \\
\text { duces negation by } \\
\text { means of but, if, (al) } \\
\text { though etc. } \\
\text { - concise and flexible } \\
\text { in form } \\
\text { - convey some kernel } \\
\text { of truth } \\
\text { - express advice } \\
\text { - memorable and } \\
\text { melodious } \\
\text { - the original proverb } \\
\text { continues to be } \\
\text { recognised within } \\
\text { the new clothing of } \\
\text { the anti-proverb }\end{array}$ & $\begin{array}{l}\text { - twist means 'to } \\
\text { pervert', 'to wring', } \\
\text { 'to turn' } \\
\text { - small, internal } \\
\text { changes in one } \\
\text { or two words on } \\
\text { the lexical, phonetic, } \\
\text { or conceptual level } \\
\text { - no rigid patterns } \\
\text { or strict rules for } \\
\text { formation except } \\
\text { one's creativity and } \\
\text { imagination } \\
\text { - memorable and } \\
\text { melodious } \\
\text { - convey a kernel of } \\
\text { truth } \\
\text { - express advice } \\
\text { - the original proverb } \\
\text { continues to be } \\
\text { recognised within } \\
\text { the new clothing of } \\
\text { the twisted proverb }\end{array}$ & $\begin{array}{l}\text { - also called pseu- } \\
\text { do-proverbs } \\
\text { - quasi means 'false', } \\
\text { 'not real', merely } \\
\text { pretending to be true } \\
\text { or genuine } \\
\text { - unusual modifica- } \\
\text { tions, which do not } \\
\text { follow elementary } \\
\text { proverbial features } \\
\text { - neither memorable } \\
\text { nor melodious } \\
\text { - long, look like ordi- } \\
\text { nary sentences } \\
\text { - may be witty, mere- } \\
\text { ly pretending to be } \\
\text { didactic } \\
\text { - tend to convey pseu- } \\
\text { do-wisdom, false } \\
\text { truth or morals } \\
\text { - present people's } \\
\text { lives in a distorting } \\
\text { mirror of proverbial } \\
\text { language } \\
\text { - pejoratively-tinged, } \\
\text { carry some negative } \\
\text { connotation } \\
\text { the original proverb } \\
\text { continues to be } \\
\text { recognised within } \\
\text { the new clothing of } \\
\text { the quasi-proverb }\end{array}$ \\
\hline
\end{tabular}

${ }^{6}$ This twisted-proverb is the title of the book Curiosity Thrilled the Cat (Magical Cats Mystery Series 1) by Sofie Kelly (2011). 
Pobrane z czasopisma New Horizons in English Studies http://newhorizons.umcs.pl Data: 26/04/2023 12:43:22

Why Money Cannot Buy Happiness. The Painful Truth about Traditional Proverbs... 13

\begin{tabular}{|c|c|c|c|c|}
\hline \multirow{2}{*}{\multicolumn{2}{|c|}{ PROVERBS }} & \multicolumn{3}{|c|}{ MODIFIED PROVERBS / PERVERBS } \\
\hline & & ANTI-PROVERBS & $\begin{array}{c}\text { TWISTED } \\
\text { PROVERBS }\end{array}$ & QUASI-PROVERBS \\
\hline 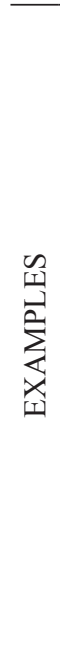 & $\begin{array}{l}\text { - Love is blind } \\
\text { - Money talks } \\
\text { - Where there is a will } \\
\text { there is a way } \\
\text { - A man is as old as } \\
\text { he feels } \\
\text { - He who laughs last, } \\
\text { laughs best } \\
\text { - Experience is the } \\
\text { best teacher } \\
\text { - Man proposes, God } \\
\text { disposes } \\
\text { - Early to bed and } \\
\text { early to rise makes } \\
\text { a man healthy, } \\
\text { wealthy and wise. }\end{array}$ & $\begin{array}{l}\text { - Love is blind, but } \\
\text { neighbors aren 't } \\
\text { - If love is blind, how } \\
\text { can there be love at } \\
\text { first sight? } \\
\text { - Never do today, } \\
\text { what you can put } \\
\text { off tomorrow vs. the } \\
\text { bona fide Never put } \\
\text { off for tomorrow, } \\
\text { what you can do } \\
\text { today (reversal of } \\
\text { order) } \\
\text { - Leap before you } \\
\text { look vs. the bona } \\
\text { fide Look before you } \\
\text { leap (reversal of } \\
\text { order) }\end{array}$ & $\begin{array}{l}\text { - Where there is a will } \\
\text { there is a won't } \\
\text { - A man is as old as } \\
\text { she feels } \\
\text { - He who laughs last, } \\
\text { thinks slowest } \\
\text { - Expedience is the } \\
\text { best teacher } \\
\text { - Man proposes, } \\
\text { mother-in-law op- } \\
\text { poses }\end{array}$ & $\begin{array}{l}\text { - Early to bed and } \\
\text { early to rise and } \\
\text { it probably means } \\
\text { your TV set is being } \\
\text { repaired } \\
\text { - Early to bed and } \\
\text { early to rise and } \\
\text { your friend will } \\
\text { wonder why you } \\
\text { can't get a job with } \\
\text { better hours }\end{array}$ \\
\hline
\end{tabular}

\section{Tradition vs. innovation in the cognitive perspective}

In the preceding section I tried to add precision to the rather chaotic paremiological terminology. In what follows, I will try and address one of the many remaining questions, namely: in what sense do bona fide proverbs serve as the basis for the creation of their modified versions and where are the limits (if any) to their formal modification. For this purpose, let us evoke the notion of profile vs. base configuration, proposed by Ronald Langacker as an elaboration of the Gestalt psychological principle of figure vs. ground. Langacker explains:

A predication always has a certain scope, and within that scope it selects a particular substructure for designation. To suggest the special prominence of the designated element, I refer to the scope and its designatum as a base and profile, respectively. [...] The semantic value of an expression resides in neither the base nor the profile alone, but only in their combination; it derives from the designation of a specific entity identified and characterised by its position within a larger configuration. (Langacker 1987: 183; emphasis original)

This definition captures three important notions. Firstly, the base is an immediate and necessary background for a profile to emerge. Secondly, profile and base are interdependent. Hence, and thirdly, only in collaboration can profile and base bring about the intended meaning. This kind of relation between profile and base may be easily transferred onto the realm of modified proverbs and their basic, original variants, re- 
spectively. The original proverb should be treated as base, whereas its idiosyncratic version as profile. If so, it really is the case that modified proverbs "should not be modified beyond recognition as it would violate the relevance principle" (Delibegović Džanić 2007: 187) and can only involve moderate changes in which "recipients recognize [them] as a modification of an established original" (Delibegović Džanić 2007: 169). In other words, the addressee should almost immediately be able to identify the old proverb in the new "clothing". Therefore, it seems that the whole principle of coining modified proverbs should comply with the notion that a proverb can be modified but it should still be recognised.

\section{Conclusion}

The key issue discussed in this paper is the relation between bona fide proverbs and their idiosyncratic modifications. The goal was to show that both traditional and new proverbs are inherently intertwined and inseparable. I have argued that twisted, ani-, and quasi-proverbs all belong to the large proverbial family with all the proverbial "privileges" (see Figure 2) and in fact they may find their place in the same large category as bona fide proverbs (cf. Mandziuk 2016).

In the introduction to this paper, the question was asked where the boundaries of proverbial creativity should be set (if there should be any at all). An answer to this query was given in section 3, which argues that through recourse to Langacker's conception of profile-base (derived from figure-ground) alignment, one may show that primary and secondary proverbs are closely intertwined, successfully complementing each other. It is crucial that a modified proverb cannot exist without its original version just as the base is essential for its profile. By discussing several examples, the paper makes an attempt to describe constraints inherent in dealing with new proverbs. New proverbs can only be included into the proverbial family under certain conditions: they have to follow at least some of the elementary proverbial principles (see section 1), out of which brevity and didactic wisdom are absolute necessities. Most importantly, some lexical and structural modifications of traditional proverbs are admissible, yet the old proverbs should still be easily identified through their modified versions.

Each proverb should be approached individually, considered in its own terms, and finally should be taken with due caution. Firstly, all members of the proverbial family pass on words of wisdom to future generations. Secondly, they successfully function only within restricted scope of events, they are not powerful enough to embrace each and every situation language speakers may find themselves in. An important aspect here is that of contextualisation, i.e. an adjustment of adages to the needs of the current

7 Delibegović Džanić's "relevance principle" pertains to elementary constituents of a given linguistic unit that are necessary to successfully link the original expression with its modified version. 
situation. And finally, modified proverbs express cultural changes, they breathe new life into the traditional adages.

To conclude, let me repeat that theoretical and analytical research into modified proverbs is still in its early stages, but it is gaining momentum, with several studies setting the course for future inquiries. Among the most influential ones are those by Wolfgang Mieder, Nihada Delibegović Džanić, or Carolie Taggart. What seems to lie ahead? One thing seems certain: all of us, as active language speakers, are capable of creating and shaping the paremiological future by bringing old proverbs up to date.

\section{Acknowledgements}

I would like to express my deep gratitude to Professor Adam Głaz for guiding me throughout the whole writing process. The completion of this paper would not be possible without his demanding, yet very inspirational eye.

\section{References}

Delibegović Džanić, Nihada. 2007. Conceptual integration theory - the key for unlocking the internal cognitive choreography of idiom. Linguistics (Jezikoslovlije) 8 (2): 169-191.

Hrisztova-Gotthardt, Hrisztalina and Melita Aleksa Varga (eds.). 2015. Introduction to Paremiology: A Comprehensive Guide to Proverb Studies. Berlin, New York, Amsterdam: Mouton de Gruyter.

Honeck, Richard. P. 1997. A Proverb in Mind: The Cognitive Science of Proverbial Wit and Wisdom. Mahwah, NJ and London: Lawrence Erlbaum.

Kuźniak, Marek. 2005. Combing 'Unkempt Thoughts': The Aphorism. Wrocław: ATUT.

Kelly, Sofie. 2011. Curiosity Thrilled the Cat. New York. The New American Library.

Lakoff, George and Mark Johnson. 2003 [1980]. Metaphors We Live By. Chicago and London: The University of Chicago Press.

Langacker, Ronald. 1987. Foundations of Cognitive Grammar. Vol. 1. Theoretical Prerequisites. Stanford: Stanford University Press.

Mandziuk, Justyna. 2016. "A Proverb a Day Keeps Boredom Away.” Anti-Proverbs, Twisted Proverbs, Perverbs and Other Animals. New Horizons in English Studies 1: 21-30. UMCS.

Mieder, Wolfgang. 1991. An apple a day keeps the doctor away. Traditional and modern aspects of English medical proverbs. Proverbium 8: 77-104.

Mieder, Wolfgang. 1993. Proverbs Are Never Out of Season: Popular Wisdom in the Modern Age. Oxford: Oxford University Press.

Mieder, Wolfgang. 2004. Proverbs. A Handbook. Westport, CT and London: Greenwood Publishing Group.

Mieder, Wolfgang and Anna Tóthné Litovkina. 1999. Twisted Wisdom: Modern Anti-Proverbs. Burlington: The University of Vermont. 
Pobrane z czasopisma New Horizons in English Studies http://newhorizons.umcs.pl Data: 26/04/2023 12:43:22

Mierzwińska-Hajnos, Agnieszka. 2013. Instances of conceptual blending in selected Polish and English modified proverbs. 7th Interdisciplinary Colloquium on Proverbs. Tavira, Portugal. International Association of Paremiology.

Norrick, Neal, R. 1985. How Proverbs Mean: Semantic Studies in English Proverbs. Berlin, New York, Amsterdam: Mouton Publishers.

Valdaeva, Tatiana. 2003. Anti-proverbs or new proverbs: The use of English anti-proverbs and their stylistic analysis. Proverbium 20: 379-390.

Taggart, Caroline. 2009. An Apple a Day: Old-Fashioned Proverbs and Why They Still Work. London: Michael O'Mara Books Limited.

Taylor, Archer. 1931: The Proverb. Cambridge, MA: Harvard University Press.

Winick, Stephen D. 2013. Proverb is as proverb does: Forrest Gump, the catchphrase and the proverb. Proverbium 30: 377-428.

Whiting, Bartlett-Jere. 1994. When Evensong and Morrowsong Accord: Three Essays on the Proverb. Cambridge: Harvard University Press. 